\title{
Analysis of Factors Influencing Job - Performance of Female Extension Agents in Owerri - West and North Areas of Imo State, Nigeria
}

\author{
${ }^{1}$ Nnadi, F.N., ${ }^{1}$ Chikaire, J., ${ }^{2}$ Atoma, C.N., ${ }^{1}$ Egwuonwu, H.A., ${ }^{1}$ Echetama, J.A. \\ ${ }^{1}$ Department of Agricultural Extension, \\ Federal University of Technology, Owerri, Imo State, Nigeria. \\ ${ }^{2}$ Department of Agricultural Extension and Managenment Technology, \\ Delta State Polytechnic, Ozoro, Delta State, Nigeria.
}

Accepted $7^{\text {th }}$ June, 2012

\begin{abstract}
One of the basic principles of agricultural extension is that extension is for all persons irrespective of age, gender, status, race and so on. Among the individuals here are both female agents and women farmers who also need and disseminate proven agricultural information and advice. This study was carried out to examine the factors influencing job-performance of female extension agents in Owerri-West and North Areas of Imo State, Nigeria. Data were obtained from 80 female extension personnel, made up of 50 female agents and 30 women in agriculture participants who serve as contact farmers due to the limited number of female agents. Data collected were analyzed using frequency distribution, percentage and mean presented in tabular form. Majority $(31.3 \%)$ are within the prime age of 36-41 years, with $27.5 \%$ having Bsc degree. They specialized in crop, animals, agric. extension and economics as well as home economics. They are involved in regular and systematic visits to villages and farms, developing rapport with farmers, solving farmers agric/farm problems, providing advisory services, monitoring/evaluating extension programs, keeping records and providing feed back to both farmers and research stations. In performance of the job as agents they are constrained by lack of education on the part of clientele, time, cash/income, beliefs and customs, slowness in adoption, social structure, farming system, lack of ability to take risk on the part of the clients among other factors. The female agents are constrained by family problems, health condition, social barriers, inadequate training and so on. Institutional factors as inadequate methodology, poor transportation network, non-payment of salaries, delays in promotion and payments, evaluation problems, corruption, lack of working materials among others hinder female agents job performance. To improve upon the above, farmers be sensitized regularly on programs and packages, salaries of agents increased, methodology be adjusted, and regular training and re-training be carried out for staff in form of seminars and workshops.
\end{abstract}

Keywords: Job - performance, extension agents, information, programs, clientele.

\section{Introduction}

There is a strong case to be made that agricultural skills training for smallholders is important in terms of creating rural growth and reducing poverty in Africa. In sub-Saharan Africa 60 - 80\% of the population is employed in agriculture, producing 30-40\% of GDP (Staatz \& Dembele, 2008; World Bank, 2007a). Smallholders account for the majority of these agricultural workers (World Bank, 2007b). They also constitute many of the poorest and most vulnerable individuals arid households, and several recent reports on poverty and food security have highlighted the importance of raising their productivity levels and ensuring that development assistance reaches them (FAO, 2003; World Bank, 2007b). The World Development Report (World Bank, 2007b) states that 'improving the productivity, profitability, and sustainability of smallholder farming is the main pathway out of poverty in using agriculture for development. It is widely acknowledged that agricultural skills training is an important part of enabling small subsistence farmers to produce the increased and reliable supplies of high quality outputs they need to benefit from higher-worth agricultural value chains. Although isolating the impact of training is challenging, as the effect of extension on productivity depends heavily on the broader environment, Evenson (2002) review of the growing body of literature on this topic nevertheless finds that the majority of extension impact studies show a statistically significant correlation between extension and yield, controlling for factors such as labour, water and fertilizer (Evenson \& Bravo-Ureta, 1994). This view has been broadly accepted by international agencies (World Bank, 2008; Rivera, 2001). Despite the promise that extension holds out, and its theoretical acceptance by major intergovernmental and aid agencies, the sector has often suffered from a lack of attention to the needs of rural communities. Wallace, Mantzou \& Taylor (1996) note that agricultural education and training in general within sub-Saharan Africa has continually failed to deliver to the needs of farmers because 'the range of skills needed by part-time farmers, subsistence producers and above all by rural women, are often ignored or are poorly addressed. The failure of extension to address the needs of rural women is a particularly stark example of the ways in which extension has been poorly orientated towards the realities of rural life in much of sub-Saharan Africa. Only training which accurately addresses the needs of women smallholders, which takes into account both their productive processes, and their needs in terms of accessing and applying training, offers serious prospects for both raising women's productivity and improving their livelihoods. While this is uncontested theoretically, the issue of agricultural extension for women nevertheless highlights one of the fundamental challenges that development currently faces. Specifically, there has been a strong recognition of the need to draw on the knowledge of local communities to deliver effective development programs in the past decade (Mansuri \& Rao, 2003). Both economic and social process of change follow the conditions of world that change rapidly. The improvement in technology, increasing transportation possibilities, widespread and efficient use of 
mass media means, organic and sustainable farming, and such changes influence rural women (Kizilaslan, 2007). The need for training together with this change has increased. The training will ensure the improvement itt human resources, the use of technology more rational along with a faster adaptation to changing life conditions. Therefore, it is necessary that women have part 5in extension training and they should not be neglected Women labor forms an important part of agricultural work force in underdeveloped and developing countries. In addition, they also carry some responsibilities related to family life at home. Therefore, the intensity of her labor is not only high in agricultural production but also high in household jobs. While women have an important share in agricultural production, they have exceedingly been deprived of agricultural services. Even in regions here agricultural activities are completely carried out by women, agricultural extension services are turned towards only men. Yet, women must have a more active role in food security, sustainable farming and rural development. This can only be achieved through supplying rural women with more qualified, reliable and convenient information continuously and quickly. Agricultural extension services are generally interested in farmers (usually assumed men), and the use of farm sources and various problems in farm management (Axinn, 1988; Hossain, 1988; Kizilaslan 2007). It is widely believed that projects employing agricultural extensionists that do not utilize female agents reach fewer women and have a negative impact not only on women's participation, but also on the sustainability of the project itself. With 25 to 30 percent of all households headed by women as their primary financial support (Colverson, 1995), the inability of projects to reach women is a major issue. If the dissemination of information bypasses women, the impact of the project may be severely limited and long-term goals sacrificed, particularly when women are heavily involved in the agricultural sector. In addition, "extension activities that are carried out without the participation of female farmer risk having negative impacts on women and their families (FAO, 1993). This paper therefore describes the socioeconomic characteristics of female agents; specific jobs performed by female agents and factors hindering the performance of female agents job.

\section{Agricultural Extension for Women}

Research shows that women constitute an increasingly large proportion of smallholders, and that both men and women farmers can benefit from training in agricultural techniques, as well as business management and marketing skills (World Bank \& IBRD, 2009). Failure to address the agricultural needs of women, including their training needs, is inefficient, and there is significant evidence that it has constrained agricultural growth. However, despite these facts, many policy makers continue to assume that women play only a supportive role in commercial agriculture and that men are the primary decision-makers World Bank \& IBRD, 2009). Agricultural technology development and extension has also largely been orientated towards men, Women farmers receive only around 5\% of extension services in sub-Saharan Africa, despite producing the majority of agricultural output. Extension activities directed at women have also historically focused on home economics, which not only reinforces traditional divisions of labour, but also leaves rural women unprepared to fill successfully the variety of roles that they are increasingly taking up (Jiggins et al., 1997). Where they have been provided, extension services for women have been criticized for being fragmented and failing, to address socio-cultural and asset differentials between men and women, and thus lacked sustainability (Das, 1995; Jiggins et al., 1997; Palmer, 2007; World Bank, 2007b). The lack of relevance of extension is often attributed to the lack of linkages between research institutes and the supposed beneficiaries. The World Development Report (World Bank, 2007b) calls for a more demand-led system and a wider role for extension agents, to be trained in areas beyond technical agriculture to build skills in mobilizing farmers, tapping market intelligence, and managing farm and non farm businesses'. These factors are even more relevant for the development of women smallholders. McGrath (2005) flags the development of skills and knowledge as the catalyst for these advancements but emphasizes that this must be accompanied by systematic targeting of gender differentials in access to and utilization of extension services and a broader enabling environment if these advancements are to maximize productivity potential.

\section{Methodology}

Imo State is located in the South East geopolitical zone of Nigeria. It is bounded on the East by Abia State, on the North by Anambra, on the west slightly by Delta and on the South by Rivers State. Imo state comprises of twenty- seven (27) local government areas and is divided into three Agricultural zones namely Orlu, Okigwe and Owerri zones. This ensures effective coverage by Imo state ADP. The State is generally situated in the rain forest of Nigeria; characterized by intermittent period of heavy, moderate and light rainfall intersperse with dry period. The two areas selected were Owerri -west and Owerri North with a population of 185.395 and 250,000 in 2012 projected from 2006 census figure. A list of 50 female extension agents was obtained from the Agricultural Development Project under the Ministry of Education. Due to the limited number of female agents, the researcher also used 30 women in agriculture (WIA) participants who serve as contact farmers, making a total of 80 female extension agents. Questionnaire was designed to collect information from the said respondents. Data collected was analyzed using frequency counts, percentages and mean presented in tabular form.

\section{Results and Discussion}

\section{Socio-economic Characteristics of Female Extension Agents}

The result reveals that majority of the women agents $(31.3 \%)$ are within the age range of $36-41$ years. They are followed by $22.5 \%$ who falls within the age bracket of $42-47$ years. This implies that majority of the female agents are young and active, hence, they are expected to be alert to their duties as change agents. Their performance as well may likely be product of their age. It was also observed that a good number of the respondents (female agents) are well educated as shown by $27.5 \%$ who have Bachelor of Science Degree, 25\% have the Higher National Diploma (HND),

How to Cite this Article: Nnadi, F.N.,Chikaire, J., Atoma, C.N., Egwuonwu, H.A., Echetama, J.A., "Analysis of Factors Influencing Job - Performance of Female Extension Agents in Owerri - West and North Areas of Imo State, Nigeria." Science Journal of Agricultural Research \& Management, Volume 2012, Article ID sjarm-252, 8 Pages, 2012. doi: $10.7237 /$ sjarm $/ 252$ 
while $12.5 \%$ have Master of Science Degree. Their levels of education here will help in handling their work effectively as it is believed that they know the rudiments of their profession very well. The study reveals also that $62.5 \%$ of the female agents are married, while $28.8 \%$ are widows who lost their husbands to death, but are still doing the work to cater for their family. On the number of dependents, otherwise called household size, 56.3\% have between 1-4 dependents in their homes. They are followed by $25 \%$ and $18.8 \%$ respectively who have between $5-8$ persons and above whom they fend for. The female agents here have large family members and this will likely affect the performance of their jobs as change agents. The study also shows that the female agents are professionals as indicated by their areas of specialization. Majority (32.5\%) trained in crop production, $28.8 \%$ trained in agricultural extension, $16.3 \%$ read agricultural economics, while $12.5 \%$ read animal science with $10 \%$ in Home economics. These are specialist in various fields of agriculture. To reach large number of farmers or clientele, $50 \%$ are village extension agents, 30\%, are subject matter specialists, while $20 \%$ serve as supervisory staff or extension officers. This means that they are likely to reach and interact with the local farmers whom they visit regularly in their farms and homes. These form the core personnel of extension who perform various duties/function.

\section{Benefits of using female agents in extension work}

The study showed that there is wisdom in the use of female agents in extension work. It was revealed that female agents have better organized groups (100\%), are more friendly and efficient in their dealings with their clientele (100\%), they also show more commitment in discharge of their duty (93.8\%), possess valuable skills and traits (67.5\%), effective at community development work (85\%), they have the ability to reach and achieve project goals (91.3\%). Other benefits of using female extension agents include their

Table 1: Socioeconomic Characteristics of Female Agents

\begin{tabular}{|c|c|c|}
\hline Characteristics & Frequency & Percentage \\
\hline \multicolumn{3}{|l|}{ Age } \\
\hline $30-35$ & 10 & 12.5 \\
\hline $36-41$ & 25 & 31.3 \\
\hline $42-47$ & 18 & 22.5 \\
\hline $48-53$ & 13 & 16.3 \\
\hline $54-59$ & 8 & $10 \cdot 0$ \\
\hline 60 and above & 6 & $7 \cdot 50$ \\
\hline \multicolumn{3}{|l|}{ Education level } \\
\hline SSCE & 5 & 6.3 \\
\hline NCE & 10 & 12.5 \\
\hline OND & 13 & 16.3 \\
\hline HND & 20 & 25.0 \\
\hline B.SC & 22 & 27.5 \\
\hline M.SC & 10 & 12.5 \\
\hline \multicolumn{3}{|l|}{ Marital Status } \\
\hline Single & 7 & 8.8 \\
\hline Married & 50 & 62.5 \\
\hline Widow & 23 & 28.8 \\
\hline \multicolumn{3}{|c|}{ Household size (Dependents) } \\
\hline $1-4$ & 45 & 56.3 \\
\hline $5-8$ & 20 & 25.0 \\
\hline 9 and above & 15 & 18.8 \\
\hline \multicolumn{3}{|c|}{ Area of Specialization } \\
\hline Crops & 26 & 32.5 \\
\hline Animal & 10 & 12.5 \\
\hline Agric. Extension & 23 & 28.8 \\
\hline Agric Economics & 13 & 16.3 \\
\hline Home Economics & 8 & $10 \cdot 0$ \\
\hline \multicolumn{3}{|l|}{ Work Position } \\
\hline VEA & 40 & 50.0 \\
\hline SMS & 24 & 30.0 \\
\hline SS/EO & 16 & 20.0 \\
\hline
\end{tabular}

How to Cite this Article: Nnadi, F.N.,Chikaire, J., Atoma, C.N., Egwuonwu, H.A., Echetama, J.A., “Analysis of Factors Influencing Job - Performance of Female Extension Agents in Owerri - West and North Areas of Imo State, Nigeria." Science Journal of Agricultural Research \& Management, Volume 2012, Article ID sjarm-252, 8 Pages, 2012. doi: $10.7237 /$ sjarm/252 
participation in extension programme (87.5\%) as easily as possible. Female extension agents can adjust easily to changing situations and culture (80\%), they easily identify with local farmers in their concerns and interests $(62.5 \%)$. During conflicts, female extension agents still this way unlike their male counterparts. The above findings are supported by Truitt (1996) who did a work on female agricultural extension agents in El Salvador and Honduras. He posited that female extension agents are sensitive to difficult situations, stressing analytical capacity, responsible, punctual and have ability to reach project goals. Evans (1984) posited that communication with women farmers is generally enhanced when female extension agents are used. This is true even in countries with relatively few social barriers to male-female interaction. Again, the existence of separate communication channels for men and women means that messages receive through male extension agents may be ignored by women farmers. Female agents will tap into women-specific networks.

There are three broad factors constraining job performance of female extension workers. These are factors associated with the farmers or clientele, factors associated with the agent herself and factors associated with the institution the agent work for or put simply, the extension organization itself. The factors associated with the clientele that constrain the female agents' job-performance are lack of education and time with mean responses of 4.50 and 3.50 respectively. Limited cash income or wealth status (2.45),

Table 2: Benefits of Using Female Extension Agents $(\mathrm{N}=80)$

\begin{tabular}{|lc|}
\hline Benefits & Percentage score \\
\hline Female agents show more commitment & 93.8 \\
Possession of valuable skills and traits & 100 \\
Effective at community development & 67.5 \\
More responsible friendly and efficient & 85 \\
Ability to reach project goals & 100 \\
More useful in conflict areas & 91.3 \\
Participate easily in extension programme & 55.0 \\
Can adjust easily to changing situation/authors & 87.5 \\
Easy identification of farmers and problems & 50.0 \\
\hline
\end{tabular}

\section{Factors Constraining female agents Job Performance}

\section{Key Performance Areas for Female Extension Personnel}

The study reveals various key job-performance areas of core extension personnel, based on category of staff. The core extension personnel comprising-village extension workers, subject matter specialists, and supervisory staff or extension officer perform roles such as making regular and systematic visits to villages and farm (100\%), developing rapport, otherwise called change relationship with clientele (100\%), keeping record of current recommendation (100\%), provision of feedback to both farmers and research stations $(87.5 \%)$, maintaining contact with research stations (96.3\%), creating opportunities to train farmers (97.5\%) reporting latest farm technology (81.3\%), planning, coordination and implementation of extension programs (83.8\%) supervise and monitor other staff, guide and evaluate extension programs, monitor use of technology, assess farmers needs desires and interests, and provide educational activities for farmers and lay leaders/opinion leaders. The above findings are in line with Adams (1982) and Williams et al., (1984) who posited that the extension worker is an adviser, a technician and a middleman operating between agricultural research institutions and the farm families. He is a change agent helping farmers to identify their problems and find their own solutions. He works for the creation of community harmony essential for group projects. He is a manger planning and organizing his work and that of his assistants. He works with other level staff who assist and achieve the programme objectives with him. The extension worker must be capable of giving farmers practical field demonstrations, of appropriate improved techniques, help them to locate farm supplies and equipment, advise them on sources of credit, and follow up their requests with the organizations involved (Adams, 1982; Williams et al., 1984). The extension agent must assume the additional role of change agent to awaken in eh people a desire for change. He must act as a catalyst, helping the farmers to identify and analyze their own problems. 
Table 3: Job Performance Areas of Female Agents (N=80)

\begin{tabular}{|c|c|c|}
\hline Job Areas & Frequency & Percentage \\
\hline $\begin{array}{l}\text { Regular \& systematic visits to } \\
\text { villages/farms }\end{array}$ & 80 & 100 \\
\hline $\begin{array}{l}\text { Developing rapport with clientele } \\
\text { (Change relationship) }\end{array}$ & 80 & 100 \\
\hline Providing advisory services to farmers & 79 & 98.8 \\
\hline Solving farmers production problems & 68 & 85.0 \\
\hline $\begin{array}{l}\text { Organizing meetings, campaigns/ } \\
\text { demonstration }\end{array}$ & 64 & 80.0 \\
\hline Creating opportunities to train farmers & 78 & 97.5 \\
\hline Keeping record of currents recommendation & 80 & 100 \\
\hline $\begin{array}{l}\text { Maintaining continuous contact with } \\
\text { research station }\end{array}$ & 77 & 96.3 \\
\hline $\begin{array}{l}\text { Provision of feed back to both farmers } \\
\text { and research station }\end{array}$ & 70 & 87.5 \\
\hline Reporting latest farm technology & 65 & 81.3 \\
\hline $\begin{array}{l}\text { Plan, coordinate and implement extension } \\
\text { programs }\end{array}$ & 67 & 83.8 \\
\hline $\begin{array}{l}\text { Supervise and monitor work done by field } \\
\text { staff }\end{array}$ & 60 & 75.0 \\
\hline Guide and evaluate extension programme & 75 & 93.8 \\
\hline Monitoring use of new technologies by clientele & 63 & 78.8 \\
\hline Assessing farmers needs, desires and aspiration & 50 & 62.5 \\
\hline Providing education activities for lay leaders & 58 & 72.5 \\
\hline
\end{tabular}

land ownership/farm size (3.05) beliefs and customs (2.50), slowness in technology adoption (2.60), social structure (3.15), social organization (3.07), farming system (2.41), lack of access to credit (3.70), and lack of risk taking ability (3.12) are clientele related factors which influences the female agents performance of her job. It was observed during the study that these factors are mainly genderrelated. Women farmers are the major group with the above characteristics then their male counterparts. The above findings are in line with Anandajayasekeram et al.,(2008) who posited that the wealth category of a farmer may affect his or her access to, and benefit from, extension services. Again, the prevailing land ownership system and size of land owned by the farmer may affect farmers access to, and benefit from extension services. In the same vein, Berger et al., (1984) said women farmers often do not have title to the land they farm and thus cannot qualify for agricultural loans; when women do have legal rights to land, their fields may be smaller and distant than those of men and, as a result, they may not be viewed as good potential clients by extensionists. The limited cash incomes of women farmers hinder their ability to purchase agricultural inputs and, particularly in the case of female managers with fewer household members available for work, to hire the necessary labour or draft power to implement new techniques disseminated by extension services. Van Crowder (1997) said literacy and access to basic education are prerequisites for taking advantage of opportunities for farm improvement. Education improves farmers abilities to innovate and make accurate agricultural decisions, yet the literacy rates of girls and women are tower than those of boys and men and as such miss opportunities for them to improve. On the influence of farming system on access to extension, Roling and Jiggins, (1994) said the private sector in extension will focus on conventional, input intensive agriculture where information is linked to inputs. Sustainable agriculture, which is recognized as knowledge intensive and requiring an approach to local learning which 
highlights local rather than external knowledge, is less likely to receive attention from commercial providers. Sustainable agriculture therefore requires much more than the adoption of new technology - it requires an entirely different paradigm shift, which can only be achieved on the basis of incremental learning. Lastly, Anandajayasekeram et al., (2008) observed that many extension providers both in the public and private (profit and non profit organizations) sectors have institutionalized the group approach for the delivery of extension services. Farmers groups and organizations have become vehicles through which farmers can pay a contribution for services, become actively involved in the planning and management of extension, and act as a voice for their members in pulling down services which meet their needs. Farmers who do not belong miss out on these opportunities. Factors emanating from the agent herself constrain job performance also. Among them are agents health condition with mean response of 4.05, family problems (3.25), social barriers and customs (3.15), inadequate training (3.05), inadequate knowledge of work (2.67), low self esteem (2.35) and lack of confidence (2.65). The family role, rural community role, and national role of women is limited by traditional approaches, that women are primarily responsible for things related with the continuity of family life, and that their participation in agricultural production is evaluated as the extended part of their responsibility make their extension teaching and training difficult. Oral interview with female agents revealed that they are not being accepted easily by male farmers and as such must provide their technical knowledge before the gained credibility. According to Kizilaslan (2007) and Collett (2010), other barriers to female agents job performance include the time tabling of training, women's perception of the relevance of the training, and their previous knowledge. The scheduling of training does not take account of the chores that women agents are expected to perform, such as cooking, cleaning and child care. Berger et al., (1984) said the effectiveness of agricultural extension agents-both men and women-depends largely upon the relevance of their training. Too often, agents have only limited agricultural training or have received very theoretical training with little practical experience. Even fewer agents have been trained in extension methods perse; they may know what message they want to deliver but not how to communicate it. Highlytechnical training may be irrelevant to the particular needs of small farmers, as it fails to provide training in the communication skills and socioeconomic orientation that extension workers need to communicate effectively at the village level (Higgs, 1976; Shaner et al, 1983). Even when field agents receive such training, it is unlikely that they will receive instruction on women's roles and their specific needs. Such training according to Benor and Baxter 91984) is crucial to refocus the efforts of all staff-both male and women. Other factors lie with the extension organization. These factors include corruption, delays in promotion of staff, late release of funds, poor remuneration and inadequate working materials with mean responses of 4.60 and 4.55 respectively. Poor transportation network (4.30), inadequate methodology and content (3.40), untimely transfer (4.15), non payment of salaries (3.37), insufficient monitoring (32.5) and evaluation problems (3.05). all these constrain job performance of female agents. Supporting the above Jiggins (1980) said salaries and allowance for government extension services staff are low, often tower than those for staff with similar qualifications in other fields, and tower than those with similar positions who are employed by commercial schemes. Allowances are often late in payment, and few other materials benefits are offered. The lack of incentives for extension field workers invites them to fulfill the stereotype held by their superiors that portrays them as spending only a fewer hours a day at work, making the minimum number of visits to the most accessible farms. The lack of incentives discourages field workers from seeking out farmers who most need their help. This group includes the majority of female farmers, who have small farms at a greater distance from the village and may be reluctant even to talk to male agent (Berger et al., 1984). In support of the above, Vijayaragavan and Singh (1997) stated that the work motivation and morale of extension staff, are very poor in many countries. The reasons being the bureaucratic structure of extension administration, lack of rewards, and incentives, poor facilities, poor promotional avenues and the low esteem given to extension. The agents are not only poorly paid but are paid late and after reminders or visit to secretariat office (Wiggins, 1986). Untimely transfers make it difficult for agents to become thoroughly knowledgeable about and involved in the problems of the local environment. Harsh climates and lack of transportation also contribute to the difficulty of the job. It is not uncommon for an agent to be expected to work without transportation or with only a bicycle, when a motorcycle or four wheel drive vehicle may be needed (Howard-Merriam, 1981). For women agents, lack of appropriate transportation is a constraints as they may be told to move motorbikes they do not train to move. 
Table 4: Factors Affecting Female Agents Job-Performance

\begin{tabular}{|c|c|}
\hline Factors & Mean Score \\
\hline \multicolumn{2}{|l|}{ Clientele factors } \\
\hline Lack of education & 4.50 \\
\hline Lack of time & 3.50 \\
\hline Limited cash income/wealth status & 2.45 \\
\hline Land ownership/farm size & 3.05 \\
\hline Beliefs and customs & 2.50 \\
\hline Slowness in technology adoption & 2.60 \\
\hline Social structure & 3.15 \\
\hline Social organization & 3.07 \\
\hline Farming system & 2.14 \\
\hline Lack of access to credit & 3.70 \\
\hline Lack of risk taking ability & 3.12 \\
\hline \multicolumn{2}{|l|}{ Agent factor } \\
\hline Family problems & 3.25 \\
\hline Inadequate training & 3.05 \\
\hline Inadequate knowledge of work & 2.67 \\
\hline Health conditions & 4.15 \\
\hline Low self-esteem & 2.55 \\
\hline Lack of confidence & 2.65 \\
\hline Social barriers \& customs & 3.15 \\
\hline \multicolumn{2}{|l|}{ Institutional Factors } \\
\hline Inadequate methodology and content & 3.40 \\
\hline Poor transportation network & 4.30 \\
\hline Non payment of salaries & 3.37 \\
\hline Untimely transfers & 4.15 \\
\hline Inadequate working materials & 4.50 \\
\hline Poor remuneration & 4.50 \\
\hline Delays in promotion of staff & 4.60 \\
\hline Insufficient monitoring of programme & 3.25 \\
\hline Evaluation problems & 3.05 \\
\hline Late release of funds & 4.55 \\
\hline Corruption & 4.60 \\
\hline
\end{tabular}

\section{Conclusion and Recommendations}

The study areas have female extension agents who are young and energetic in careering out their assignment. Majority are educated as they possess high education certificates. They are specialists in their various fields and work in various capacities. They keep records, make regular visits, train and educate farmers, fill forms and correspond with the research stations, provide feedback to both farmers and research, plan, coordinate, evaluate, monitor and supervise extension programs. Multiple factors affect the performance of their job. These include lack of education, time, wealth status, title to land, access to credit, family problems, health conditions, inadequate training, lack of confidence, social barriers, lack of knowledge of work, poor transportation, non payment of salaries among others. To improve, we recommend that rural farmers be sensitized on programs to make then accept packages, increase salaries, promote regularly, adjust methodology to incorporate women needs, and organize regular training seminars and training for female agents.

\section{References}

1. Adams, M.E. (1982) Agricultural Extension in Developing Countries Longman, United Kingdom.

2. Anandajayasekeram, P., Puskur R., Workneh, S. and Hoekstra, D. (2008) Concepts and Practices in Agricultural Extension in Developing Countries: A Sourcebook. International Food Policy Research Institute, Washington, D.C.

3. Axinn, G.H. ((1988) Guide to Alternative Extension Approaches. Food and Agriculture Organization, Rome.

4. Benor, D. and Baxter, M. 91984) Training and Visit System. The World Bank, Washington, D.C.

5. Berger, M., Delancey, V. and Mellencamp, A. (1984) Bridging the Gender Gap in Agricultural Extension. International Centre for Research on Women, Washington, D.C.

6. Collett, K. (2010) Responding] to Demand Agricultural training for Women Farmers. City and Guide Centre for Skills and Development, United Kingdom. 
7. Colverson, K.E. (1995) What Do Women Want? Case studies of Women's Needs for Agricultural programming> Convergences xxviii (3).

8. Delancey, V. (1984) Agricultural Extension for Women in Cameroon. A Case Study, Mineo.

9. Das, M. 91995) Improving the Relevance and Effectiveness of Agricultural Extension Activities for Women Farmers. Food and Agricultural Organization, Rome.

10. Evans, J. (1986) Phalombe Rural Development Project: Study Funded by British Government Overseas Development Association, Blantyre, Malawi.

11. Evenson, R. (2002) Economic Impacts of Agricultural Research and Extension. In Gardener, B. and Rausser, G. (Eds) Handbook of Agricultural Economics, Elsevier, London.

12. Evenson, R. and Bravo-Ureta, B. (1994) Efficiency in Agricultural Production: The Case of Peasant Farmers in Eastern Paraguay. Agricultural Economics 10(1): 27-37.

13. FAO (1993) Agricultural Extension and Farm Women in the1980s. Food And Agriculture Organization, Rome.

14. FAO (2003) World Agriculture: Towards 2010/2030: An FAO Perspectives Food and Agriculture Organization, Rome.

15. Higgs, J. (1976) Extension in Latin America Montetair, New Jersey, America.

16. Howard-Merriam, K. (1981) The Female Rural Development Administrator in Egypt: A Case of Under-cultivated Potential . Paper Presented at the Middle East Studies Association 15th Annual Meeting Seattle, Washington, D.C. 4th-7th November.

17. Hossain, M. (1988) Nature and Impact of the Green Revolution in Bangladesh, Research Report 67. International Food Policy Research Institute, Washington, D.C.

18. Jiggins, J. (1980) Female-Headed Households Among Subsistence Cultivators in the Central and Northern Province of Zambia. Paper Presented at Workshop on Women in Agricultural Production in Eastern and Southern Africa. Nairobi. 9th - 11th April.

19. JIggens, J. Samanta, R. and Olawoye, J. (1997) Improving Women Farmers. Access to Extension Services. In Swanson, B., Bentz, R. and So Franko, J. (Eds) Improving Agricultural Extension: A Reference Manual. Food and Agricultural Organization, Rome.

20. Kizilaslan, N. (2007) Rural Women in Agricultural Extension Training. Research Journal of Social Sciences 2:23-27.

21. Mansuri, G. and Rao, V. (2003) Evaluating Community-Based and Community Driven Development: A Critical Review of the Evidence World Bank, Washington, D.C.

22. Mc Grath, S. (2005) Skills Development for Rural People: A Renewed Challenges. International Cooperative in Skills Development, Geneva.

23. Palmer, R. (2007) Skills Development: The Enabling Environment and Informal Micro-Enterprise in Ghana. PhD Dissenlation, University of Edinburgh, London.
24. Rivera, W. (2001) Agricultural and Rural Extension Worldwide: Options for Institutional Reform in the Developing Countries, Food and Agriculture Organization, Rome.

25. Roling, N. and Jiggins, J. (1994) Policy Paradigm for Sustainable Farming. European Journal of Agricultural Education and Extension 7 (1): 23-44.

26. Shanner, W.W., Philip, P.F. and Schenehl, W.R. (1982) Farming System Research and Development: Guidelines for Developing Countries > West View Press, Boulder, Calorado.

27. Staalz, Y. and Dembele, N. (2008) Agriculture for Development in Sub- Saharan Africa. Background Paper for World Development Report 2008. Michigan State University, United States.

28. Truitt, G.A. (1996) Female Agricultural Extension Agents in El Salvador ands Hondural. Do they have an Impact.

29. Van Crowder, L. (1997) Women in Agricultural Education and Extension. Food and Agriculture Organization, Rome.

30. Vijayaragaran, K. and Singh, Y.P. (1997) Managing Human Resources within Extension. In Swanson, B., Bentz, R.P. and Sofranka, A.J. (eds) Improving Agricultural Extension: A Reference Manual. Food and Agriculture Organization, Rome.

31. Wallace, I., Mantzou, K. and Taylor, P. 91996) Policy Options for Agricultural Education and Training in Sub-Saharan Africa. Agricultural Extension and Rural Development Department, University of Reading, Britain.

32. Williams, S.K.T., Fenley, J.M. and Williams, C.E. (1984) A Manual For Agricultural Extension Workers in Nigeria. University of Ibadan, Ibadan.

33. Wiggins, S. (1986) Agricultural Policy and Agricultural Extension: The African Experience. In Jonas, G.E. (eds) Investing in Rural Extension; Strategies and Goals. Elsevier Applied Services, London.

34. World Bank (2007a) Cultivating Knowledge and Skills to Grow Africa Agriculture. World Bank, Washington D.C.

35. World Bank (2007b) World Development Report 2008: Agriculture for Development. World Bank, Washington, D.C.

36. World Bank and IBRD (2009) Gender in Agriculture Sourcebook. World Bank/International Bank for Reconstruction and Development, Washington, D.C. 